\title{
TINJAUAN DESAIN WEBSITE KEMLU.GO.ID
}

\author{
Danu Widhyatmoko \\ Jurusan Desain Komunikasi Visual, School of Design, BINUS University \\ Jln. K. H. Syahdan No. 9, Palmerah, Jakarta Barat 11480 \\ danu@binus.edu
}

\begin{abstract}
Review of kemlu.go.id website design is a research report on Kemlu.go.id website design. Kemlu.go.id website aims to be the information gateway of Ministry of Foreign Affairs, and also as guidelines of foreign politic policies of Republic of Indonesia. The review had been accomplished by using analytical method based on the "Nine Essential Principles for Good Web Design" developed by Collis Ta'eed (2007). At the end of the article, several recommendations in developing kemlu.go.id website are presented to create better appearance.
\end{abstract}

Keywords: review, web-design, kemlu.go.id

\begin{abstract}
ABSTRAK
Tinjauan desain website kemlu.go.id adalah tulisan hasil penelitian terhadap desain website Kemlu.go.id. Website kemlu.go.id diperuntukkan sebagai pintu gerbang informasi Kementrian Luar Negeri Republik Indonesia (Kemlu RI) dan rujukan kebijakan politik luar negeri Republik Indonesia. Tinjauan dilakukan dengan menggunakan metode kajian merujuk kepada "Nine Essential Principles for Good Web Design" yang dikembangkan oleh Collis Ta'eed (2007). Pada bagian akhir tulisan disampaikan rekomendasi untuk mengembangkan website kemlu.go.id agar dapat tampil lebih baik.
\end{abstract}

Kata kunci: tinjauan, desain website, kemlu.go.id 


\section{PENDAHULUAN}

Website kemlu.go.id diperuntukkan sebagai pintu gerbang informasi Kementrian Luar Negeri Republik Indonesia (Kemlu RI) dan rujukan kebijakan politik luar negeri Republik Indonesia. Menteri Luar Negeri RI sendiri berharap agar Kemlu.go.id dapat menjadi media yang berfungsi sebagai pilar bagi kebijakan luar negeri dan diplolasi. Selain itu diharapkan dapat menjadi media yang efektif bagi penyampaian informasi Kemlu ke stakeholders.

Selain itu, landasan yang akan digunakan tentunya adalah Visi yang dimiliki oleh Kemlu RI yakni memajukan kepentingan nasional melalui diplomasi total. Landasan Misi yang sejalan dengan aktivitas website kemlu.go.id yakni Misi (4) Meningkatkan citra Indonesia melalui diplomasi publik, dan (6) Meningkatkan pelayanan keprotokolan, kekonsuleran, fasilitas diplomatik dan perlindungan WNI/BHI di luar negeri yang cepat, ramah, mudah, transparan dan akuntabel. Sedang Tujuan Kemlu RI yang sejalan meliputi (5) Memperkuat citra Indonesia melalui penyediaan informasi yang akurat dan peningkatan pemahaman pemangku kepentingan di dalam negeri dan masyarakat internasional terhadap politik luar negeri, dan (7) Meningkatkan kualitas dan kapasitas pelayanan keprotokolan, kekonsuleran, fasilitas diplomatik dan perlindungan WNI/BHI di luar negeri. Peruntukkan, visi, misi serta tujuan dari Kemlu.go.id tersebut menjadi landasan dalam melakukan tinjauan desain Website Kemlu.go.id, apakah website yang kini ada mampu menjawab harapan yang disandangnya.

Lingkup tinjauan desain website kemlu.go.id akan difokuskan kepada area desain website saja, terkait dengan elemen yang masuk ke area desain, termasuk di dalamnya kegunaan dan manfaat dilihat dari sisi pengguna, dan konsistensi yang dijalankan.

\section{METODE PENELITIAN}

Pendekatan analisis yang dilakukan dengan membuat kajian atas Website kemlu.go.id merujuk kepada "Nine Essential Principles for Good Web Design" yang dikembangkan oleh Collis Ta'eed (2007). Sembilan prinsip tersebut meliputi: Precedence, Spacing, Navigation, Design to Build, Typography, Usability, Alignment, Clarity (Sharpness), dan Consistency.

Namun dalam kebutuhannya, sembilan prinsip tersebut coba untuk lebih disederhanakan agar tidak terjadi pengulangan baik di dalam penilaian di wilayah tampilan/web design maupun terhadap hasil analisis lain yang terdapat dalam Tinjauan \& Analisis Website Kemlu.go.id. Karena itu unsur prinsip tersebut dikemas ulang menjadi: 1) Navigation (Elemen Nagivasi): bagaimana elemen-elemen visual yang ada mampu mengarahkan gerak mata sesuai dengan arah informasi dan komunikasi yang diharapkan; 2) Spacing \& White Space (Jarak/jeda, Ruang Kosong): apakah terdapat ruang-ruang jeda, ruang kosong sebagai lahan istirahat mata sehingga mata tidak mengalami kelelahan pada saat mengakses informasi yang tersedia; 3) Typography (Tipografi): website berjenis pusat informasi, jenis huruf memiliki fungsi yang sangat penting karena menentukan tingkat kenyamanan pengunjung untuk mendapatkan informasi yang ada; 4) Hierarchy (Hierarki): bagaimana informasi yang ada dapat disajikan secara terstruktur dan mudah dimengerti, dari halaman depan hingga halaman yang semakin dalam; 5) Usability (Kegunaan dan Manfaat): seberapa informatifnya data yang dimiliki dan seberapa interaktifnya web tersebut kepada pengunjungnya; 6) Design to Build (Desain): apakah semua elemen utama desain terdapat di web tersebut? Balance, Contrast , Emphasis, Rhythm, Unity; 7) Consistency (Konsistensi): apakah terdapat konsistensi antar-elemen visual yang terdapat di dalam website kemlu.go.id. 
Tinjauan ini disusun menggunakan pendekatan studi literatur untuk mendapatkan data-data pendukung serta mencari kerangka teori guna menguatkan hasil penulisan. Kemudian setelah data-data didapatkan, maka akan dilakukan analisis data refletif. Analisis Reflektif adalah metode analisis data yang berpedoman pada cara berfikir reflektif. Pada dasarnya metode ini adalah kombinasi yang kuat antara berfikir deduktif dan induktif atau dengan mendialogkan data teoretis dan data empiris secara bolak balik kritis (Stain, 2002: 16).

Dengan metode analisis reflektif, penulis mencari makna yang terkandung dari hasil pengumpulan data yang telah dilakukan, untuk diperbandingkan antara literatur yang ada dengan keadaan ataupun fenomena yang tertangkap. Sehingga dapat diperoleh kesimpulan data yang rasional dan ilmiah.

Untuk memudahkan kesamaan persepsi serta pemahaman dalam pengukuran, maka tinjauan desain website kemlu.go.id ini juga akan dilengkapi dengan sistem penilaian sederhana yang mudah dan terukur, yaitu:

Tabel 1 Sistem penilaian untuk mengukur tingkat kualitas website kemlu.go.id

\begin{tabular}{|c|c|c|c|c|}
\hline$\star$ & & & & Tidak tersedia \\
\hline$\star$ & $\star$ & & & Tersedia namun berkualitas buruk \\
\hline$\star$ & $\star$ & $\star$ & & Berkualitas baik \\
\hline$\star$ & $\star$ & $\star$ & $\star$ & Berkualitas maksimal \\
\hline
\end{tabular}

\section{HASIL DAN PEMBAHASAN}

\section{Elemen Navigasi}

Elemen-elemen visual yang ada mampu mengarahkan gerak mata sesuai dengan arah informasi dan komunikasi yang diharapkan.

\section{Navigasi}

Navigasi sendiri secara mudah memiliki dua elemen "sedang berada di mana" dan "akan menuju ke mana". Navigasi pada Website Kemlu.go.id relatif bersifat tradisional. Hanya mengandalkan deret alamat halaman berupa teks dan memanfaatkan letak baris di area header menu utama dan peletakan pada bagian head submenu. Padahal, banyak unsur lain yang bisa dimanfaatkan, misalnya warna dan elemen desain.

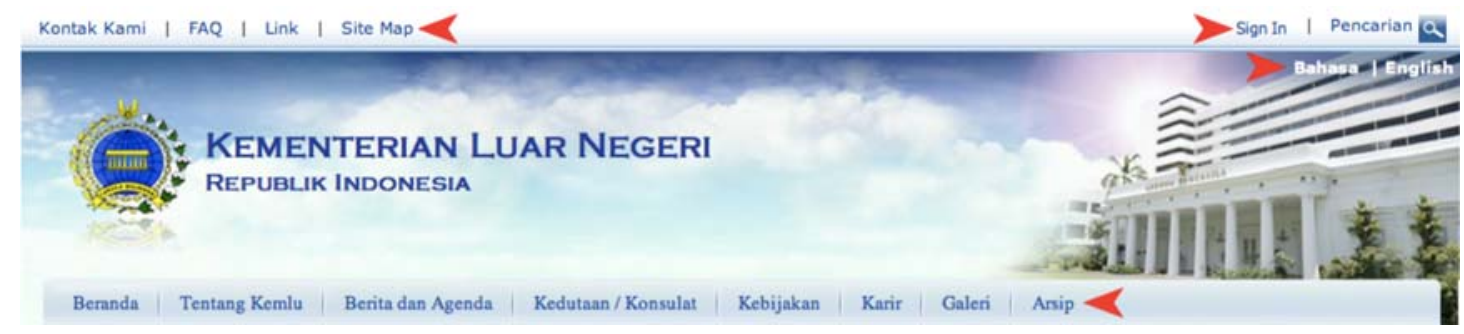

Gambar 1 Peletakan navigasi utama berupa link teks 
Saat masuk ke halaman dalam, maka sistem navigasinya pun terbilang tradisional, kembali mengandalkan teks sebagai link. Penempatan submenu pada sisi kiri bukanlah menjadi satu keharusan, malah submenu tersebut tidak dapat berperan secara maksimal, karena dengan fungsi yang sama dapat dengan mudah mengakses lewat submenu pada header menu. Drop-down menu yang digunakan pun sangat sederhana, sedang saat ini tren terhadap drop-down menu sudahlah sangat jauh perkembangannya, dengan pendekatan beragam warna serta elemen desain, hingga yang berukuran besar (mega drop-down menu).

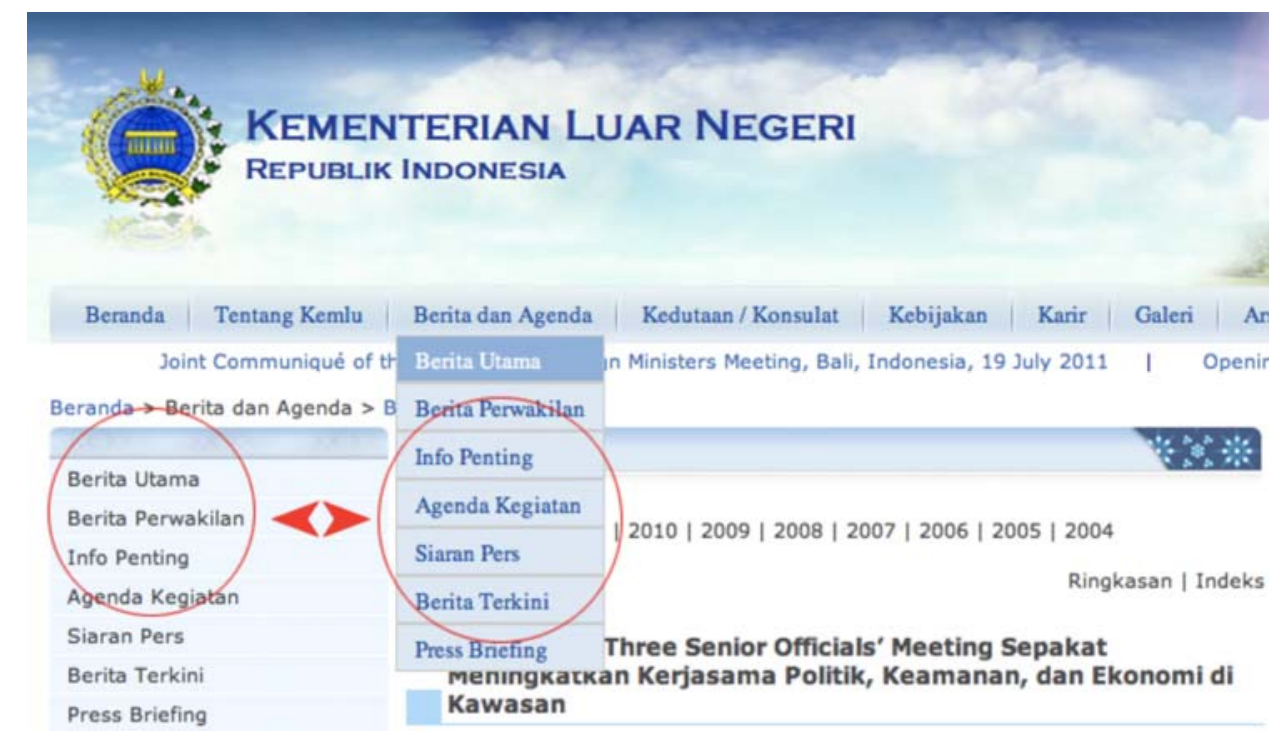

Gambar 2 Peletakan navigasi pada halaman dalam menunjukkan pengulangan di area yang berdekatan, antara submenu dengan drop down menu

Terdapat masalah pada navigasi link berupa teks, karena tidak terdapat sistem pembeda yang jelas yang dapt menunjukkan teks tertentu itu berupa link yang dapat diklik. Juga tidak terdapat konsistensi dalam mouse over. Tidak seluruhnya terjadi perubahan pada saat sebuah teks link didekatkan oleh mouse.

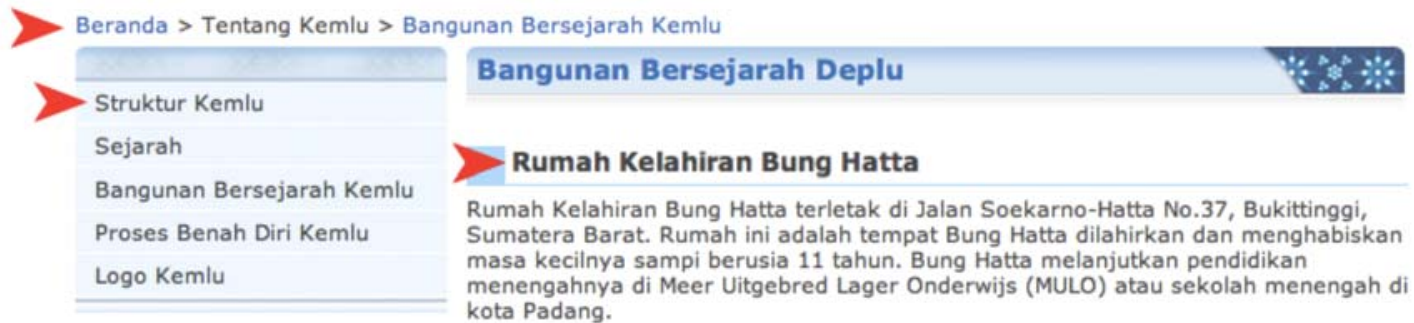

Gambar 3 Teks yang ditunjukkan oleh panah merah berfungsi sebagai link, namun tidak terlihat sebagai link, dan hanya teks link "Rumah Kelahiran Bung Hatta” saja yang memiliki fasiltas mouse over berupa underlined text

Nilai :

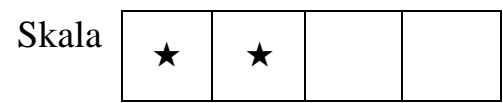




\section{Posisi Web Keseluruhan}

Relatif baik karena pada saat ukuran browser diperkecil dan diperbesar tidak terlalu bermasalah, dan konsisten berada di tengah. Tes juga dilakukan lintas browser, menggunakan browser Chrome, Safari, FireFox, relatif tidak terjadi masalah. Kebutuhan untuk hadir di mobile gadget dapat menjadi pertimbangan berikutnya, karena saat ini belum mendukung area tersebut.

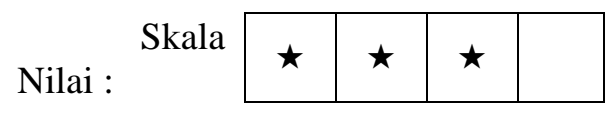

\section{Warna}

Walau sudah dicoba untuk menampilkan warna yang diambil dari logo Kemlu RI, dengan cara mereduksi intensitas kepekatan warnanya, namun secara umum masih relatif kurang baik karena tidak dapat mencerminkan semangat yang dimiliki oleh Kemlu RI, semestinya warna-warna asli logo Kemlu RI dapat turut dihadirkan dengan maksimal, agar nuansa yang tercipta akan semakin memvisualkan semangat dari Kemlu RI itu sendiri. Penerapan warna yang terdapat pada website Kemlu RI saat ini sepertinya terkendala oleh keterbatasan template yang digunakan.

Selain warna biru yang mendominasi, terdapat 2 warna lain yang dapat digunakan sebagai aksen, yakni kuning dan hijau. Bila memang skema warna yang ingin dikembangkan menggunakan pendekatan monokrom (nuansa satu warna) - biru misalnya - akan lebih baik warna yang digunakan tetap didominasi oleh warna putih agar kesan elegan, bersih, terpercaya mudah tercipta dan jajaran nada warna dapat diperluas dengan menambahkan nilai warna yang lebih pekat.
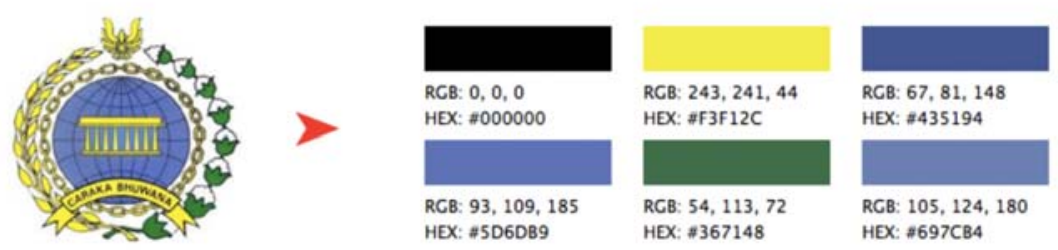

Gambar 4 Palette warna yang terdapat pada logo Kemlu RI

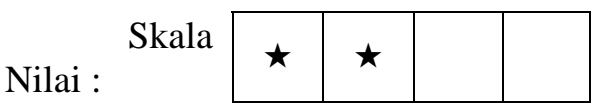

\section{Ukuran}

Pada dasarnya tidak terdapat masalah mendasar dengan ukuran web yang dimiliki oleh website kemlu.go.id. Lebar website yang dimiliki website kemlu.go.id selebar 980px. Ukuran ini sepertinya mengikuti standar ukuran yang dimiliki oleh template Microsoft SharePoint yang dimiliki oleh Kemlu RI. Bila mengikuti kaidah standar ukuran web yang berkembang, semestinya mengacu kepada grid system 960px.

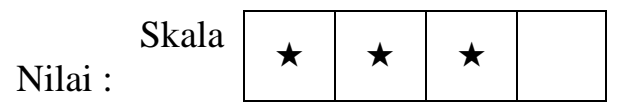




\section{Elemen Web}

Terdapat dua elemen website yang jelas terlihat di Website kemlu.go.id, yakni elemen grafis dan icons. Elemen grafis yang digunakan berupa pattern yang diletakkan di latar area submenu. Elemen ini tidak memiliki makna dan fungsi, tidak memiliki relevansi dengan Kemlu RI terlebih apabila diharapkan untuk membangun citra.

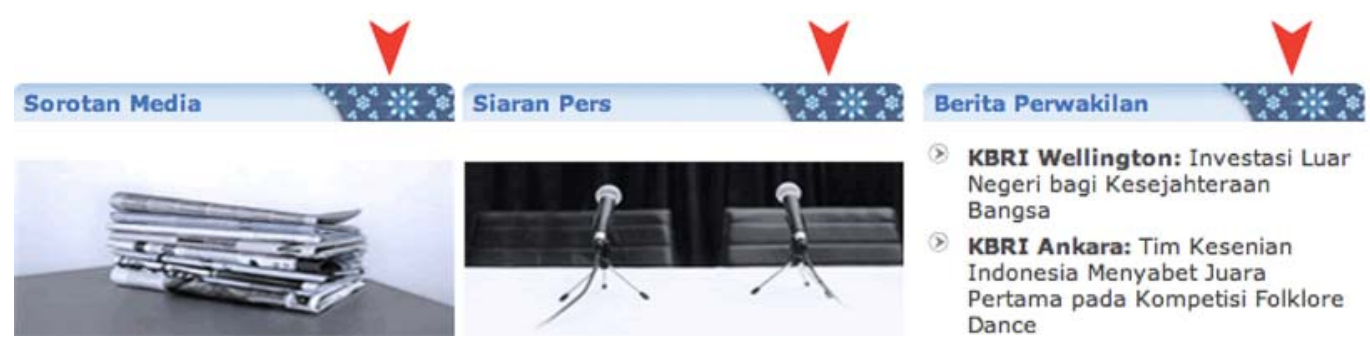

Gambar 5 Elemen Grafis pada website kemlu.go.id

Elemen grafis berupa icons masih menggunakan pendekatan visual yang telah ditinggalkan, yakni piktogram dua dimensi. Efek visual yang diharapkan berupa kemudahan untuk mengingat link yang dikaitkan (asosiasi) tidak mudah didapat karena visual yang digunakan bersifat umum dengan warna yang sangat pudar dengan skema warna yang tidak dapat dijelaskan asalnya/landasannya.

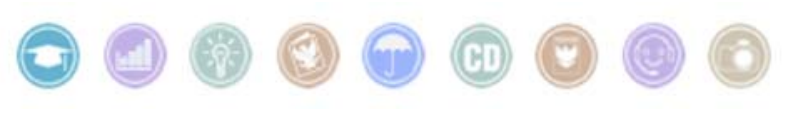

Gambar 6 Elemen Grafis pada Website kemlu.go.id

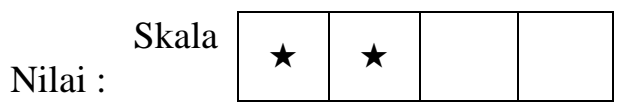

\section{Jarak Jeda/Ruang Kosong}

Apakah terdapat ruang-ruang jeda, ruang kosong sebagai lahan istirahat mata, hingga mata tidak mengalami kelelahan dalam mengakses informasi yang tersedia? Website kemlu.go.id tersaji dengan tingkat kepadatan yang tinggi, jarak antar sub-area itu yang disarankan setidaknya selebar/setinggi 20px, namun yang terdapat di Website kemlu.go.id didominasi oleh ukuran 10px. Kondisi tersebut salah satunya yang memicu terciptanya kepadatan ruang. Di area tertentu, yang semestinya terdapat jarak yang baik, seperti jarak antar menu (padding) malah tidak tergarap. Pilihan ukuran huruf yang relatif kecil dipadu dengan spasi (line spacing) yang ketat menimbulkan kelelahan mata pada saat membaca. 


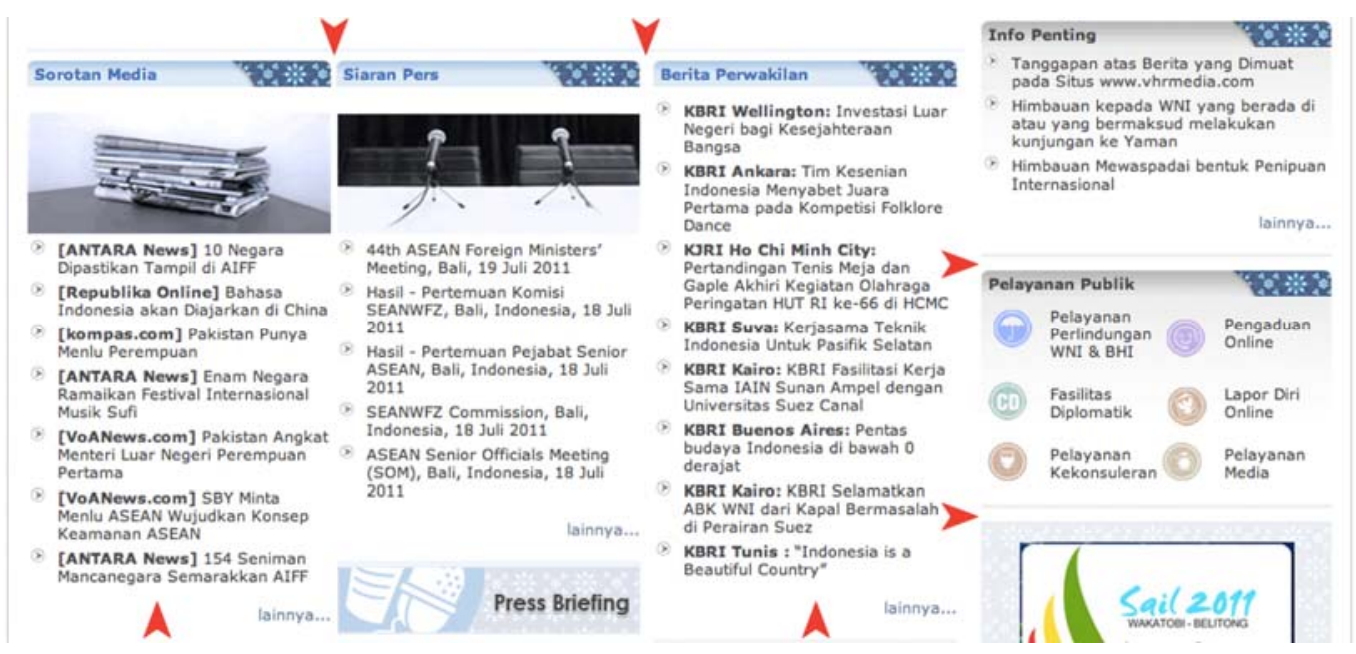

Gambar 7 Anak panah merah menunjukkan tingkat kepadatan yang tercipta di website kemlu.go.id

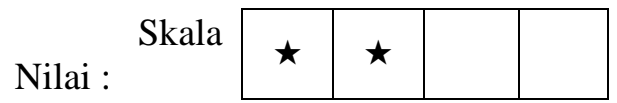

\section{Tipografi}

Untuk web berjenis pusat informasi, jenis huruf memiliki fungsi yang sangat penting karena menentukan tingkat kenyamanan pengunjung untuk mendapatkan informasi yang ada.

\section{Pilihan Jenis Huruf}

Menggunakan pilihan huruf yang relatif aman - Verdana - hingga memungkinkan diakses dengan baik oleh OS yang ada. Pilihan huruf semisal Verdana, Arial, Tahoma, Helvetica untuk bodytext tidak akan memberikan masalah, karena memang sudah teruji dengan baik keterbacaannya. Namun untuk pilihan font yang diperuntukkan sebagai head, subhead dapat dicari jenis font lain yang dapat mencitrakan Kemlu RI sebagai institusi negara yang berwibawa.

Penggunaan jenis font Copperplate pada image utama pada head area bertuliskan Kementrian Luar Negeri Republik Indonesia tidak tepat karena tidak fleksibel/tidak universal, lebih mencirikan satu kultur tertentu, padahal Kemlu harusnya universal ke semua negara. Terlebih jenis huruf tersebut sudah ditinggalkan, untuk itu dapat dipilih jenis font lain yang lebih sesuai.

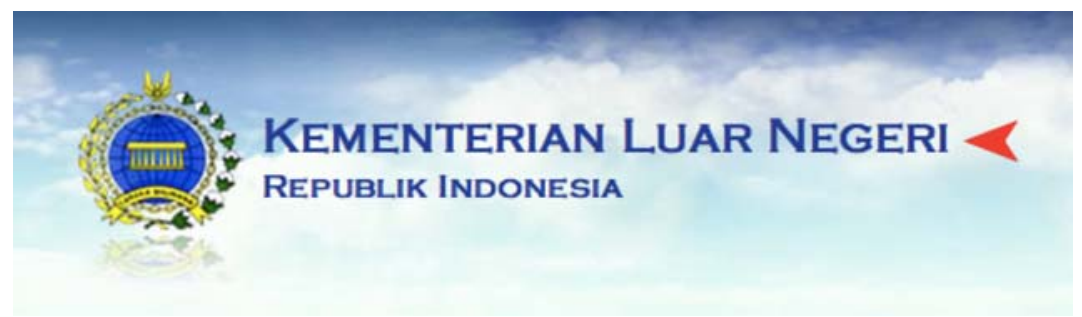

Gambar 8 Jenis font yang digunakan pada tulisan Kementrian Luar Negeri Republik Indonesia menggunakan Copperplate tidak dapat mencerminkan institusi negara dan sudah tertinggal eranya. 
Saat mencoba mengakses website kemlu.go.id dari beberapa browser dan PC, maka ditemukan ketidakkonsistenan pada font yang digunakan pada menu utama. Salah satu penyebabnya bisa dikarenakan oleh sistem CSS yang tidak baik.

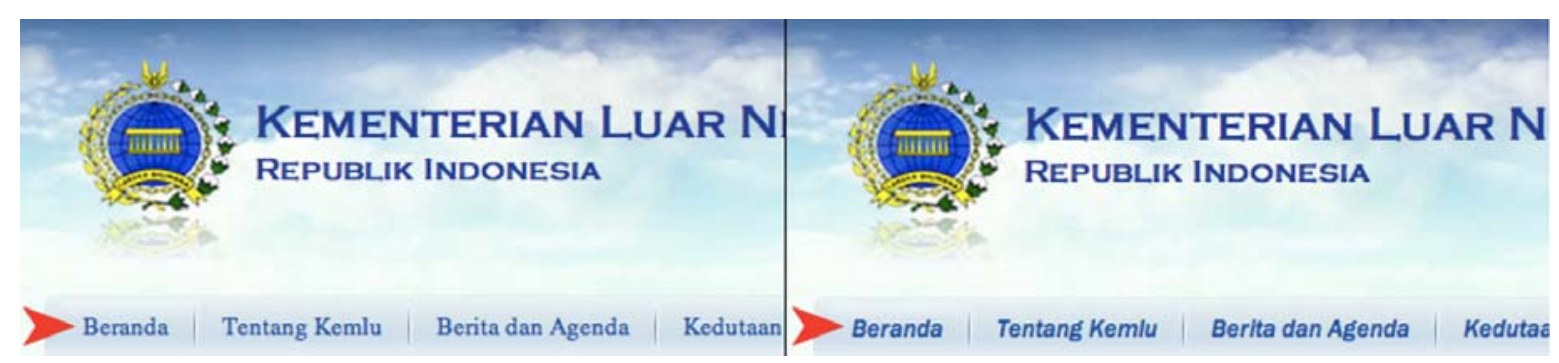

Gambar 9 Ketidakkonsistenan penggunaan jenis font saat diakses lewat dua browser dari PC yang berbeda, jenis font pada capture kiri berjenis Serif sedang sebelah kanan berjenis Sans Serif

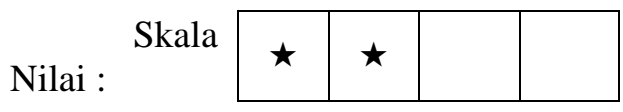

\section{Ukuran Huruf}

Tidak ada pemanfaatan ukuran huruf sebagai sarana hierarki dan navigasi. Hanya pemanfaatan case menjadi uppercase/huruf kapital saja. Sehingga, beda antara heading - sub heading - text menjadi tidak terlihat dengan baik.

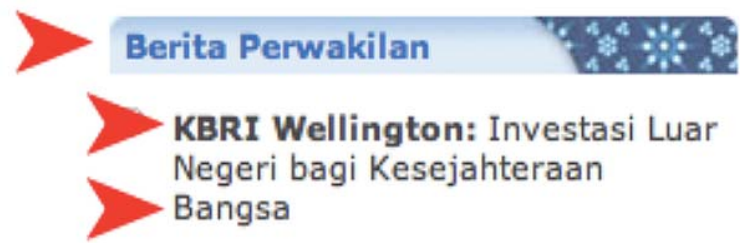

Gambar 10 Beda antara heading - sub heading - text menjadi tidak terlihat dengan baik.

Ukuran teks untuk artikel yang ada juga terlalu kecil, hingga melelahkan mata saat membaca. Trend serta kebutuhan yang berkembang di area teks saat ini membutuhkan ukuran teks yang lebih besar, minimal 12 points untuk jenis font berukuran besar, dan kini didominasi oleh ukuran 14 points. Sedang ukuran teks pada website kemlu.go.id adalah 11 points.

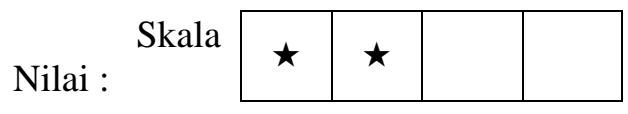

\section{Spasi}

Terlalu padat, terlebih ditambah dengan ukuran huruf yang kecil. 


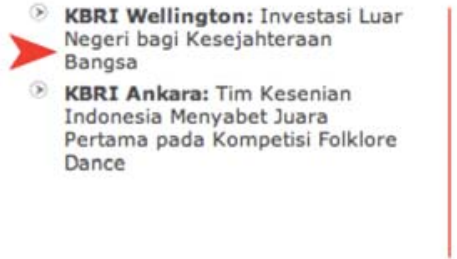

HOME
Isu Regional dan Internasional yang akan dibahas dalam Pertemuan Tingkat Menlu Kamis ini (21/7) diantaranya adalah isu Semenanjung Korea, upaya-upaya untuk memperkuat kerjasama di fora internasional seperti G-20 dan PBB, juga kerjasama di bidang disaster management and response.

Dalam area ekonomi, APT SOM juga membuat proposal mengenai review dan implementasi dari Chiang Mai Initiative Multilateralisation (CMIM), operasionalisasi dari APT Macroeconomic Research Office (AMRO) sejak Mei 2011, upaya untuk meliberalisasi perdamic Research Offe (AMRO) sejak MPT meliberalisasi perdagangan di antara negara anggota APT, revitalisasi dari East Asia Forum
(EAVG) II.

INSIDE PAGE

Gambar 11 Capture yang menunjukkan spasi teks dari halaman muka dan dalam website kemlu.go.id

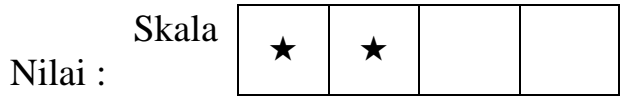

\section{Panjang Ruang Baca}

Lebar area baca baik di bagian depan (home/beranda) website maupun di bagian dalam (inside page) berkualitas baik, mata tidak akan nyaman pada saat membaca karena area teks/baca tidak terlalu lebar.

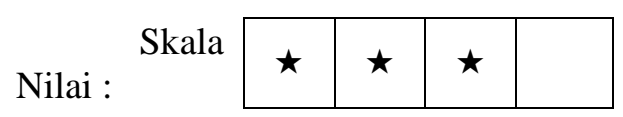

\section{Warna Huruf}

Pada body text relatif tidak terlalu bermasalah, kontrasnya terjaga, nyaman untuk dibaca. Ini dikarenakan warna teks hitam yang diletakkan di atas latar putih. Namun untuk mengurangi lelahnya mata akibat kontras warna, dapat digunakan warna abu-abu yang pekat.

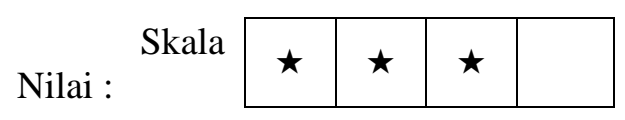

\section{Hierarki}

Hierarki berhubungan dengan informasi yang ada dapat disajikan secara terstruktur dan mudah dimengerti, dari halaman depan hingga halaman yang semakin dalam. Pemanfaatan template bawaan dari sebuah CMS (semisal Microsoft SharePoint) memang akan memudahkan. Pola hierarki yang diberikan pun tipikal aman, merujuk kepada pola arah mata dan letak informasi di bagian atas adalah yang utama lalu bergerak ke kanan lalu ke bawah. Namun di dalam penempatan serta peruntukannya sebaiknya merujuk kepada visi, misi serta tujuan dari keberadaan dari website kemlu.go.id. Bila merujuk kepada hal tersebut, hierarki yang dapat disusun adalah menyediakan informasi yang akurat seputar aktivitas politik luar negeri Indonesia dan meningkatkan kualitas dan kapasitas pelayanan bagi WNI/BHI di luar negeri.

Dua agenda tersebut dapat dituangkan dalam bentuk kualitas informasi yang komprehensif dan kemudahan mendapatkan pelayanan lewat website kemlu.go.id bagi WNI/BHI di luar negeri. Dua agenda tersebut harus mendapatkan tempat yang utama di website kemlu.go.id, dengan porsi yang berimbang.

Bila melihat halaman utama website kemlu.go.id, hierarki tersebut belum dapat tersampaikan dengan baik. Secara porsi, lebih jelas terlihat bahwa poin utama, yakni informasi mendapat porsi yang lebih dominan ketimbang Pelayanan. Termasuk dalam area Informasi adalah Berita Terkini, Berita 
Utama, Sorotan Media, Siaran Pers, Berita Perwakilan, Info Penting, Aktivitas Menteri Luar Negeri, Agenda Kegiatan. Sedang porsi Pelayanan hanya terwakili oleh Tips dan area Pelayanan Publik. Area Pelayanan Publik tersebut menjadi wadah untuk enam jenis pelayanan krusial yang semestinya dapat diekspos satu persatu karena menjadi tujuan utama dari keberadaan dari website kemlu.go.id ini.

Tabel 2 Tabel perbandingan poin Informasi dan Layanan yang terdapat pada website kemlu.go.id

\begin{tabular}{|c|c|}
\hline $\begin{array}{c}\text { Informasi Seputar Aktivitas Politik } \\
\text { Luar Negeri Indonesia }\end{array}$ & $\begin{array}{c}\text { Kualitas dan Kapasitas Pelayanan Bagi } \\
\text { WNI/BHI di Luar Negeri }\end{array}$ \\
\hline $\begin{array}{ll}\text { - } & \text { Berita Terkini } \\
\text { - } & \text { Berita Utama } \\
\text { - } & \text { Sorotan Media } \\
\text { - } & \text { Siaran Pers } \\
\text { - } & \text { Berita Perwakilan } \\
\text { - } & \text { Info Penting } \\
\text { - } & \text { Aktivitas Menteri Luar Negeri } \\
\text { - } & \text { Agenda Kegiatan }\end{array}$ & $\begin{array}{ll} & \text { Tips } \\
\bullet & \text { Area Pelayanan Publik }\end{array}$ \\
\hline
\end{tabular}

Pola cara kerja website adalah mengakar hierarkis, dari hal yang paling umum hingga terus mendalam ke hal yang paling khusus (mendetail). Jadi sangatlah dimungkinkan dengan sistem kategorisasi yang baik maka berita-berita yang kini tersajikan dalam porsi yang banyak dapat dikelompokkan dan disajikan dengan lebih efisien, tidak perlu mengambil porsi sedemikian besar. Kemudian informasi yang bersifat data - ini termasuk data hasil pertanyaan dan jawaban - dapat dikelompokkan menjadi satu area tersendiri, tidak harus mendapatkan posisi hierarki yang tinggi. Begitupun dengan kegiatan-kegiatan yang didukung oleh Kemlu RI, tetap dapat dipilih yang paling utama saja, atau dapat disajikan dengan pendekatan image/banner slider.

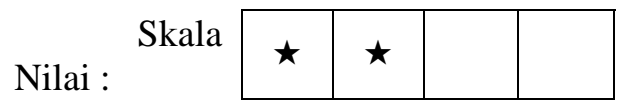

\section{Kegunaan dan Manfaat}

Menyangkut seberapa informatif data yang dimiliki dan seberapa interaktif website tersebut kepada pengunjungnya.

\section{Informasi}

Data yang tersedia relatif baik, tersaji secara konsisten dan hadir secara cepat (update). Data pendukung pun terdapat dengan lengkap, yang masih menjadi kendala adalah bagaimana menyajikan begitu banyaknya data yang ada dengan baik, hingga mudah untuk diperoleh kembali, mudah untuk diakses oleh siapapun yang membutuhkan tanpa harus melibatkan tim internal Website Kemlu.go.id, cukup mengaksesnya lewat website saja.

Namun pada saat mengakses fitur Tips yang berisi Belajar di Luar Negeri, Potensi Ekonomi Luar Negeri, Tips Perjalanan dan Menetap, penyajian yang awalnya sangat menjanjikan, berupa tampilan berdasar wilayah benua, lalu masuk ke berbagai negara, tetapi pada saat diakses tidak terdapat datanya, masih kosong.

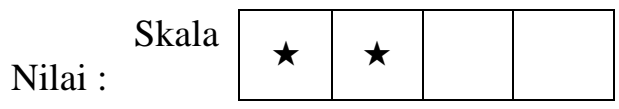




\section{Interaktif}

Interaksi dari pengunjung menjadi salah satu poin krusial dari keberadaan website kemlu.go.id, karena poin ini menjadi salah satu tujuan utama dari keberadaan website. Interaksi yang baik memungkinkan terciptanya layanan yang berkualitas terutama bagi WNI/BHI yang sedang berada di luar negeri. Interaksi dapat diartikan sebagai kemudahan komunikasi dari pengunjung dan pihak pemiliki website. Interaksi tidak dapat diartikan secara sempit sebagai bentuk 'gerak' saja.

Bila meninjau pemanfaatan kanal interaktif yang terdapat di Website kemlu.go.id, akan dijumpai tiga kanal yang dapat digunakan, yakni: Kontak Kami di area header, Lapor Diri Online pada area Pelayanan Publik, Pengaduan Online pada area Pelayanan Publik.

\section{Kontak Kami}

Link tersebut membawa ke dalam halaman seluruh alamat yang dapat menghubungi dengan pihak Kemlu RI. Penyajian alamat-alamat tersebut sangat padat, tidak tersaji dengan kaidah penyajian yang memudahkan mata untuk membaca. Selain itu, ada baiknya formulir online Kontak Kami yang tersedia lebih dikedepankan, diletakkan di atas lalu setelah itu baru daftar alamat-alamat. Agar pengunjung lebih mudah untuk menghubungi Kemlu RI secara langsung lewat fasilitas formulir online yang telah disediakan.

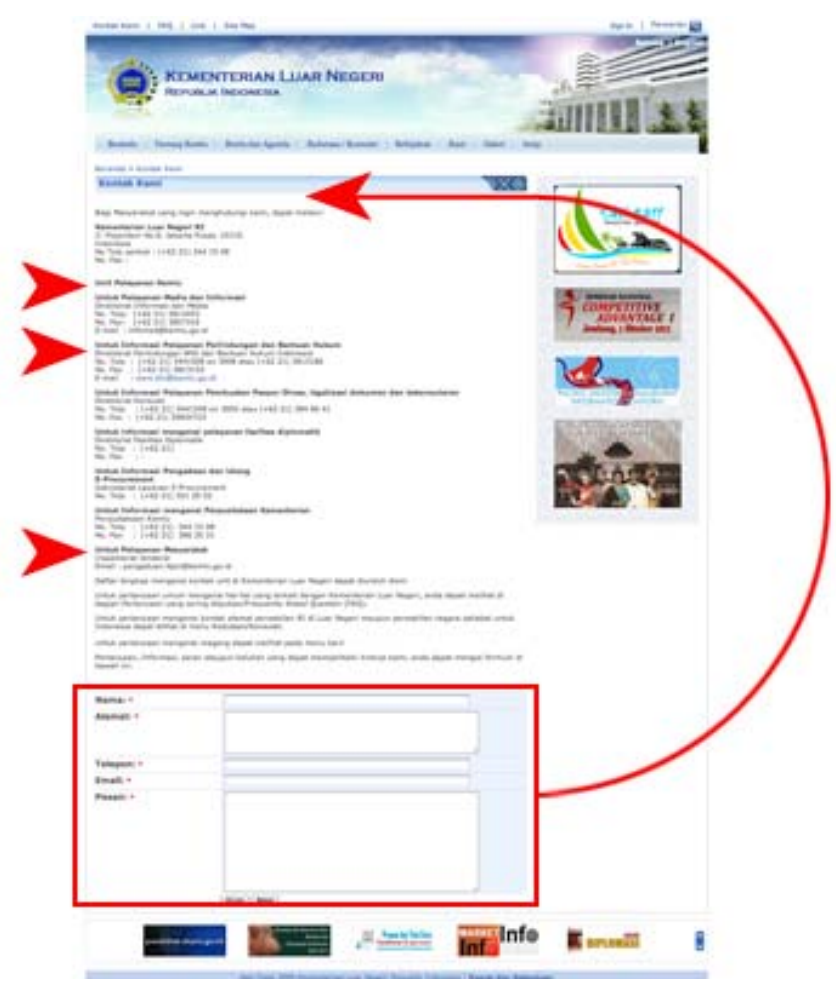

Gambar 12 Panah merah di sebelah kiri menunjukkan tingkat kepadatan informasi. Arah panah kanan menunjukkan penempatanan yang sebaiknya dilakukan.

\section{Lapor Diri Online}

Fasilitas ini bertujuan untuk memudahkan warga negara yang sedang berada di luar negeri untuk melakukan lapor diri ke Kedubes RI setempat. Formulir online yang disediakan semestinya dapat disajikan dengan lebih baik, mudah untuk mengisisinya. Panjang jarak antara pertanyaan dan 
pilihan jawaban, serta tidak tersedianya penanda jeda antar pertanyaan menambah sulitnya mengisi formulir online tersebut.

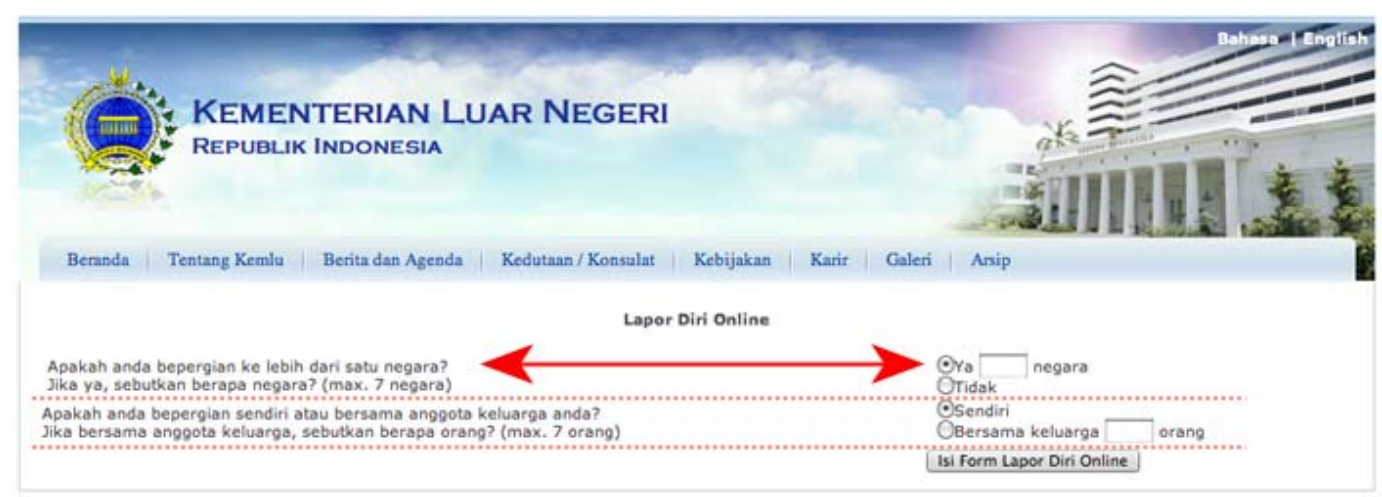

Gambar 13 Panah merah menunjukkan jarak yang terlalu lebar antara pertanyaan dan jawaban dari formulir online. Garis putus-putus merah menunjukkan penanda jeda yang sebaiknya tersedia untuk memudahkan pengunjung yang ingin mengisi formulir online tersebut.

\section{Pengaduan Online}

Kesulitan terbesar dalam membuat sebuah formulir online adalah bagaimana caranya menyajikan kotak isian seminimal mungkin. Dalam kasus penyajian formulir online Pengaduan Online ini hal tersebut sulit dipenuhi, karena kebutuhann minimalnya memang sebanyak itu. Untuk menyiasatinya dapat membuat area grup yang jelas, agar membantu dalam pengisian dan juga jarak antara pertanyaan serta kotak jawaban tidak terlalu jauh. Agar kemudahan dapat lebih tercapai dapat juga dibantu dengan menggunakan penanda jeda, dapat berupa warna, elemen visual semisal garis juga.

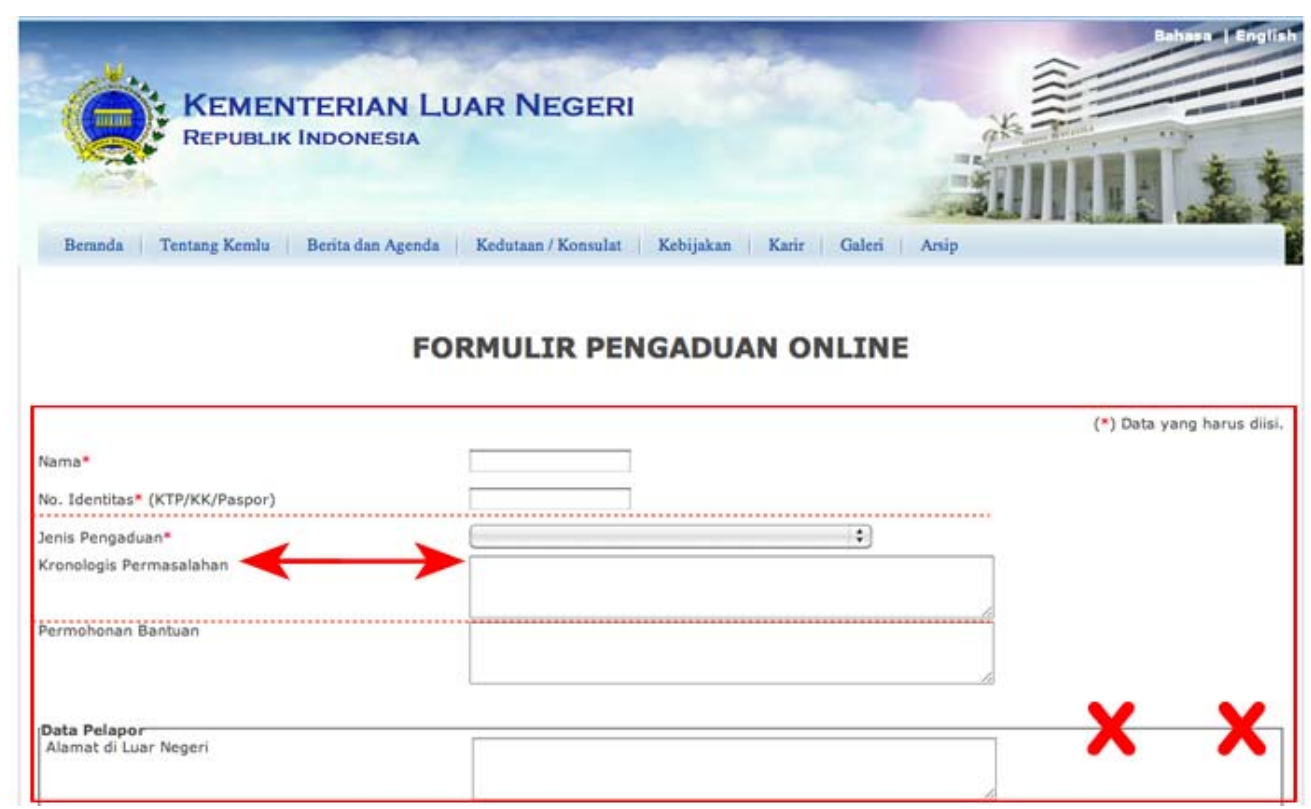

Gambar 14 Panah merah menunjukkan jarak yang terlalu lebar antara pertanyaan dan jawaban dari formulir online. Garis putus-putus merah menunjukkan penanda jeda yang sebaiknya tersedia untuk memudahkan pengunjung yang ingin mengisi formulir online tersebut. Tanda silang menandakan sebaiknya dua area formulir online tersebut disatukan saja, tidak perlu dipisah. 


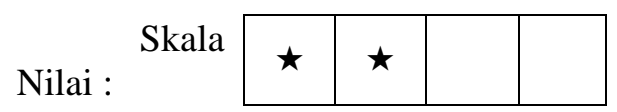

\section{Desain}

Apakah semua elemen utama desain terdapat di web tersebut?

\section{Balance}

Area kiri bawah yang terbiarkan kosong membuat tampilan website kemlu.go.id pada saat diakses lewat browser di area bawah menjadi tidak seimbang, terlalu berat di kanan. Secara keseluruhan, dikarenakan tampilan beranda website kemlu.go.id didominasi oleh teks di sebelah kiri dan banner iklan di sebelah kanan berupa gambar-gambar maka website tersebut cenderung semakin berat ke kanan.
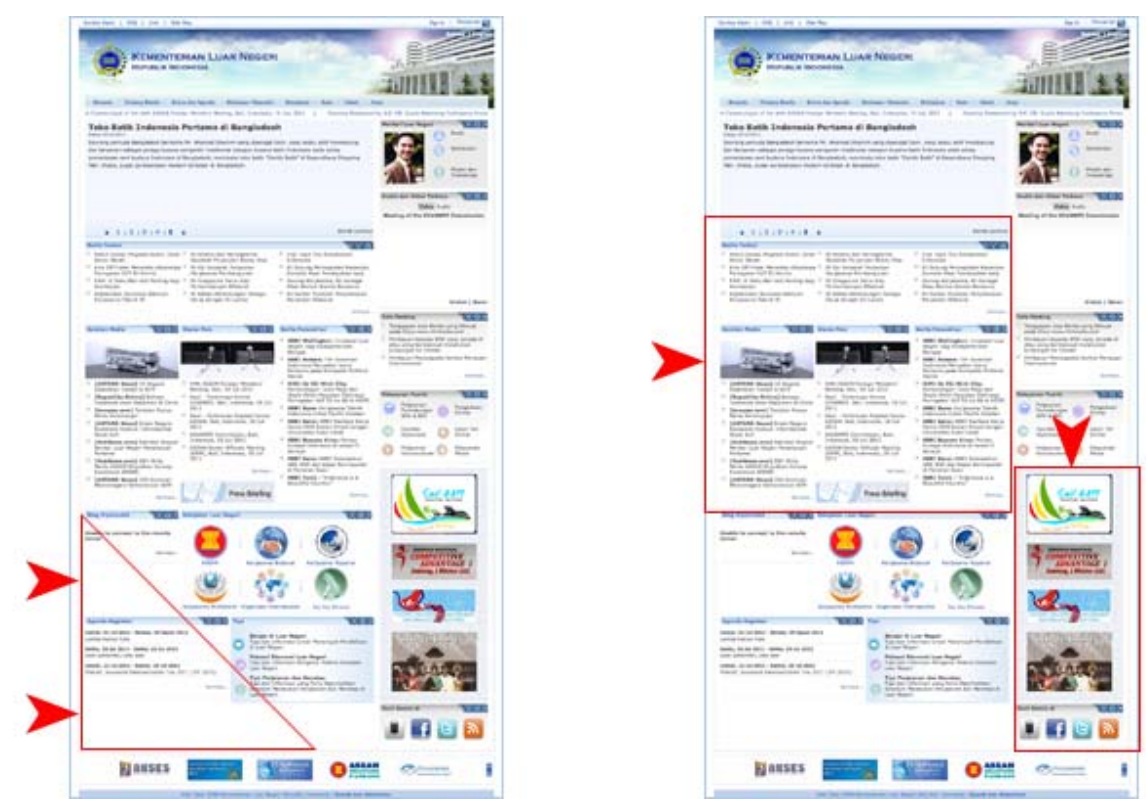

Gambar 15 Panah merah di kiri menunjukkan area kosong yang relatif besar.

Panah merah di sisi kanan menunjukkan ketidakseimbangan antara sisi kanan dan kiri website dikarenakan dominasi antara teks dan gambar yang tidak imbang.

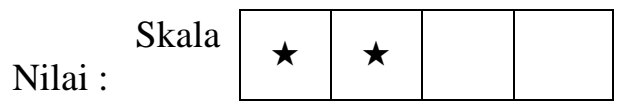

\section{Contrast}

Tidak ada hal contrast (kontras) yang baik diterapkan di web ini, tiap halaman datar saja. Kontras malah terjadi pada sajian banner/iklan yang disajikan, mengingat iklan-iklan kegiatan tersebut tersaji lewat warna yang kuat dan variatif.

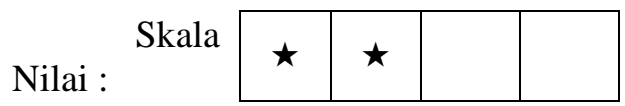




\section{Emphasis}

Seperti halnya contrast, tidak terdapat penekanan yang baik di tiap halaman yang diakses, semua halaman datar saja.

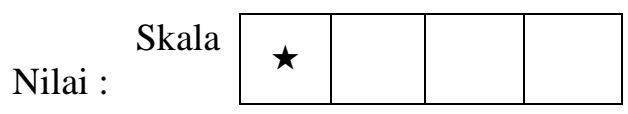

\section{Rhythm}

Pengulangan visual yang terjadi lebih karena bawaan template standar yang digunakan oleh website kemlu.go.id. Semestinya dapat ditambahkan dengan elemen desain yang bersifat personal atau bisa juga dalam bentuk infografis yang semakin menjelaskan.

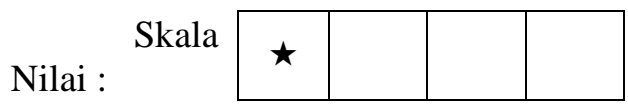

\section{Unity}

Tidak terdapat kesatuan antar-elemen website yang ada, termasuk antar-halaman (dikarenakan tidak terdapat satu sistem). Termasuk jenis banner, sistem penyajian gambar, visual head banner yang tidak mampu mengesankan website kemlu.go.id secara menyeluruh.

Dua hal yang telah berusaha dijaga adalah warna biru pudar yang digunakan. Warna tersebut pun tidak dapat menggambarkan kekuatan diplomasi yang diharapkan dari citra yang ingin ditampilkan oleh kemlu.go.id. Lalu berikutnya adalah icons penyerta subhead. Icons tersebut tersaji dalam warna pudar dan tidak memiliki kesatuan dengan keutuhan desain yang terdapat di website kemlu.go.id.

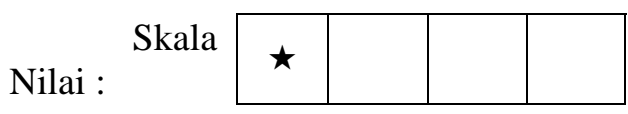

\section{Konsistensi}

Pada dasarnya website kemlu.go.id berhasil menampilkan konsistensi di dalam penyajian. Hal ini dikarenakan hasil dari penggunaan Content Management System Microsoft SharePoint yang telah digunakan. CMS MSP tersebut menyajikan template standar yang relatif telah tertinggal eranya. Sehingga, konsistensi yang telah dicapai tidak dapat menyajikan desain sebuah website yang menarik untuk dikunjungi dalam waktu yang lama.

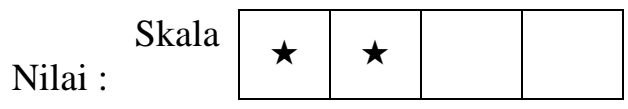

\section{SIMPULAN}

Berdasarkan analisis, secara umum dapat dikatakan website kemlu.go.id tidak dapat menyajikan desain yang baik, setelah dilakukan penilaian relatif unsur-unsur desain yang ada hanya mencapai tahap "ada” saja, menjadi satu satu bentuk kelengkapan saja. Penyajian desain yang tidak maksimal akan berdampak kepada informasi yang akan tersaji menjadi tidak maksimal, hingga tujuan utama yang disandang oleh website kemlu.go.id tidak dapat tercapai. Termasuk di dalamnya adalah citra visual yang ingin ditangkap sebagai cerminan semangat, visi dan misi pun akan sulit tercapai. 
Ketidakmaksimalan desain yang dimiliki oleh website kemlu.go.id dimulai dari keterbatasan template desain yang dimiliki oleh Content Management System, Microsoft SharePoint. Template tersebut tidak leluasa menghadirkan desain yang sesuai dengan kebutuhan dari website kemlu.go.id. Hingga akhirnya keterbatasan tersebut menjadi kendala krusial yang berdampak besar pada kualitas desain website kemlu.go.id. Layout yang sangat masif, elemen desain yang tidak tergarap, pendekatan tipografi yang tertinggal, contrast-emphasis-rhythm-unity yang tidak dapat ditemui, menjadikan website kemlu.go.id semakin minim dalam kualitas desain.

Interaksi yang menjadi kata kunci dalam kemudahan teknologi informasi juga tidak tersaji di website kemlu.go.id. Padahal kemudahan interaksi berupa pelayanan publik menjadi salah satu tujuan utama dari website kemlu.go.id, sebagai bagian dari tujuan utama, yakni kualitas dan kapasitas pelayanan bagi WNI/BHI di luar negeri.

\section{Rekomendasi}

Ada baiknya site-map yang disusun - termasuk sistem hierarki pengelompokkan - untuk website kemlu.go.id diarahkan untuk mampu menjawab visi, misi dan tujuan yang dimiliki oleh Kemlu RI. Porsi hierarki yang ada, nantinya dapat disusun berdasar persentase visi, misi, dan tujuan yang dimiliki. Hingga, apabila kita mengakses dari halaman awal pun, website kemlu.go.id dapat hadir menyajikan fungsi yang dimiliki dan tampilan yang sesuai dengan peruntukannya.

Website kemlu.go.id sebaiknya mampu menyajikan unsur desain yang baik, tidak hanya menjadi unsur kelengkapan saja. Untuk memaksimalkan tiap unsur desain yang ada, maka sudah sepatutnya website ini dikembangkan menggunakan penyesuaian (customize desain) yang sesuai dengan peruntukkan website terkait, bukan berangkat dari keterbatasan template yang dimiliki oleh CMS yang digunakan.

Sedang untuk peran interaksi yang terdapat di website kemlu.go.id dapat dimulai dengan menciptakan formulir online yang mudah dalam melakukan pengisian. Elemen desain dan navigasi yang baik dapat dimanfaatkan untuk lebih menjelaskan navigasi yang mengarahkan ke area layanan yang mengedepankan interaksi. Pada dasarnya website kemlu.go.id ini harus mampu menyajikan sarana interaksi/komunikasi dari para pengunjung ke pihak Kemlu RI dengan cara yang mudah dan cepat. Saat ini hal tersebut dapat dicapai dengan menggunakan fasilitas formulir online yang modern, chat box, serta integrasi sosial media, lalu ditempatkan pada area webiste yang dianggap strategis.

\section{DAFTAR PUSTAKA}

Marcus, A. (1993). SIGGRAPH 93 tutorial notes: Graphic Design for User Interfaces.

Ta'eed, C. 17 Desember 2007). 9 Essential Principles for Good Web Design. Diakses pada 1 Agustus 2011 dari http://psd.tutsplus.com/tutorials/designing-tutorials/9-essential-principles-for-goodweb-design/. 